\title{
SUPREMO TRIBUNAL FEDERAL: ATIVISMO OU SELF-RESTRAINT NA EFETIVAÇÃO DE DIREITOS SOCIAIS?
}

\author{
Ana Paula Oliveira Avila ${ }^{1}$ \\ Paula Mandagará Miranda ${ }^{2}$
}

\begin{abstract}
Resumo
O objetivo da presente pesquisa é apresentar diferentes situações de intervenção judicial nas políticas públicas no âmbito do Supremo Tribunal Federal, especialmente no que diz respeito à satisfação de direitos sociais. A partir de revisão documental e jurisprudencial, empreendeu-se uma análise quanti-qualitativa, considerando 45 acórdãos que tinham por objeto a satisfação de direitos sociais, divididos em dois grupos - distinguindo as hipóteses de tutela individual e coletiva desses direitos. Em cada amostragem, apontamos os argumentos que justificam as orientações fixadas pelo STF, identificando na jurisprudência da Corte as situações em que predominam o ativismo ou a autocontenção judicial. A análise qualitativa das razões de decidir permitiu deduzir, ainda, uma possível tendência jurisprudencial futura, consubstanciada na via da cooperação institucional.
\end{abstract}

Palavras-chave: Supremo Tribunal Federal; Direitos Sociais; Ativismo Judicial; Judicialização; Políticas Públicas.

\section{INTRODUÇÃO}

O objetivo deste trabalho é aferir, a partir da análise de casos, de que forma o Supremo Tribunal Federal (STF) vem se posicionando a respeito da possibilidade de efetivação de direitos sociais pelo Poder Judiciário nos casos de omissão dos Poderes Legislativo e Executivo no que tange à formulação e execução das políticas públicas de cunho social ${ }^{3}$.

A atuação do Judiciário nesta área vem se tornando cada vez mais frequente. Na medida em que a Constituição estrutura um sistema político social-democrático e, para o que interessa aos fins deste estudo, um amplo leque de direitos sociais fundamentais de cunho prestacional, do Estado é exigida uma atuação positiva no sentido de atender às necessidades sociais. Paralelamente, no plano empírico, os fins almejados pela Constituição

\footnotetext{
${ }^{1}$ Doutorado em Direito pela UfRGS (2007). Professora Titular de Direito Constitucional e Direito Econômico dos Cursos de Graduação e Mestrado - UniRitter (Porto Alegre). Coordenadora Adjunta do Programa de Pós-Graduação Stricto Sensu Mestrado em Direito do UniRitter (Porto Alegre).E-mail: ana_avila@uniritter.edu.br

2 Bolsista CAPES do Mestrado em Direitos Humanos - UniRitter (2015) - linha de pesquisa Direitos Humanos e Direitos Fundamentais. E-mail: paulamandagara@gmail.com

${ }^{3}$ Como observa APPIO, as políticas públicas estão divididas em políticas públicas de natureza social e de natureza econômica, as quais se complementam a fim de atingir uma finalidade comum, "a de impulsionar o desenvolvimento da Nação, através da vol.10, nº. 01, Rio de Janeiro, 2017.pp. 519-543 
Federal de 1988 (CF/88) seguem longe da concretização, restando grande parte da população sem acesso a uma gama de direitos constitucionalmente garantidos. Em face desta realidade de escassez, do Judiciário passa a ser exigida uma postura ativa a fim de garantir de forma célere a efetividade destes direitos prestacionais ${ }^{4}$.

Não há, porém, consenso acerca da legitimidade das decisões judiciais que, com o fim de concretizar direitos sociais, impõem aos demais Poderes deveres prestacionais por meio do controle das políticas públicas. Por um lado, há quem entenda que são inteiramente legítimas, na medida em que, ao tornarem efetivos direitos fundamentais constitucionalmente previstos, nada mais fazem do que respeitar a Constituição, antes violada pela omissão dos demais Poderes. Por outro lado, tais decisões são tidas como expressão de ativismo judicial, por acarretar uma ingerência indevida na esfera dos Poderes Legislativo e Executivo, que são aqueles competentes para implementar e executar as medidas necessárias para a efetivação dos direitos sociais, função esta que escapa às atribuições do Poder Judiciário.

O objetivo deste trabalho é sistematizar a forma pela qual o STF vem exercendo a tutela dos direitos sociais de cunho prestacional (que dependem de políticas públicas para serem efetivados), para então analisar se há uma predominância de alguma orientação específica na jurisprudência da Corte quanto aos limites do exercício da função jurisdicional no controle das políticas públicas. Apoiado em metodologia de pesquisa de revisão documental, bibliográfica e jurisprudencial, o exame a ser efetuado sobre as decisões judiciais consiste em uma análise valorativa, a partir da qual pretende-se estabelecer se há um traço preponderante na jurisprudência que permita concluir se o STF adota uma posição ativista ou se exerce a autocontenção - self restraint.

Para tanto, foram selecionados 45 (quarenta e cinco) acórdãos proferidos pelo STF entre os anos de 2004 e 2016 (não foram incluídas as decisões monocráticas em razão da grande quantidade em que se apresentam na jurisprudência - teriam que ser analisadas em torno de 1.000 decisões, o que não seria compatível com as limitações deste trabalho, e nem as decisões monocráticas expressam a orientação predominante da Corte, senão que, geralmente, apenas a orientação do seu prolator). Sua seleção foi feita a partir da ferramenta de busca disponível no sítio do STF, no campo "Pesquisa de Jurisprudência”, com a utilização dos seguintes argumentos de busca: "políticas públicas e direitos fundamentais" e "separação dos poderes e políticas públicas"; de todos os acórdãos obtidos, foram excluídos aqueles que não se referiam a políticas públicas sociais de cunho prestacional', um que tratava de dever prestacional decorrente de responsabilidade civil do Estado e outro em que não era possível identificar o direito tutelado, do que resultou num total de 45 (quarenta e cinco) acórdãos.

melhoria das condiçoes gerais de vida de todos os cidadãos" (APPIO, Eduardo. Controle Judicial das Políticas Públicas no Brasil. Curitiba: Juruá, 2005, p. 136)

${ }^{4}$ RAMOS, Elival da Silva. Ativismo Judicial- Parâmetros Dogmáticos. São Paulo: Saraiva, 2010, p. 268-74, passim.

${ }^{5}$ Em geral, eram casos de controle material ou forma de constitucionalidade de leis ou atos normativos, demandas cujo resultado não implicou a imposição de um dever prestacional ao Poder Executivo. 
A análise empreendida estrutura-se da seguinte forma: a primeira parte centra a problemática que envolve a efetivação dos direitos sociais pelo Poder Judiciário nos casos de omissões inconstitucionais. Em seguida, apresentamos o conceito de ativismo judicial e os critérios utilizados para verificação desta prática nos julgados selecionados, para então, no tópico seguinte, apresentarmos os julgados pesquisados. Em seguida passamos à análise dos julgados, que será dividida em duas partes, uma relativa aos casos de demanda individual dos direitos sociais e a outra acerca dos julgados em que a demanda se deu de forma coletiva ${ }^{6}$, ao longo das quais faremos um contraponto com questões doutrinárias e com os critérios de identificação do ativismo. Optamos pela análise em separado de acordo com titularidade (individual ou coletiva) a fim de observar se existe alguma diferença na forma de atuação do STF em razão do tipo de demanda. Por fim, nas considerações finais, explicitaremos a tendência predominante na posição adotada pelo STF e os motivos pelos quais chegamos a tal conclusão.

\section{ENTRE AS OMISSÕES INCONSTITUCIONAIS E A EFETIVAÇÃO: AS DIFICULDADES EM TORNO DA JUDICIALIZAÇÃO DOS DIREITOS SOCIAIS}

A Constituição Federal de 1988 prevê uma série de direitos sociais, estabelecendo que cabe ao Estado o dever de garanti-los. O dever estatal, porém, com poucas exceções, é previsto de forma genérica, não havendo uma especificação de quais são as prestações devidas para o fim de garantir-se a fruição destes direitos. Em razão da forma de positivação, as normas veiculadoras de direitos sociais são denominadas de normas-princípio ${ }^{7}$, por possuírem um caráter eminentemente finalístico sem definir concretamente os meios de se atingir o fim estabelecido. A fim de serem concretizadas, tais normas necessitam de "providências situadas fora ou além do texto constitucional”, dependendo de medidas de ordem material para conformação da realidade fática'. A baixa densidade normativa dos dispositivos leva à indeterminação do conteúdo do direito e, consequentemente, dos deveres correspondentes.

\footnotetext{
${ }^{6}$ Optamos pela análise em separado dos casos de tutela coletiva e dos casos de tutela individual a fim de observar se existe alguma diferença na forma de atuação do STF em razão do tipo de demanda. Acerca da dupla titularidade dos direitos econômicos, sociais, culturais e ambientais cf. HACHEM, Daniel Wunder. A dupla titularidade (individual e transindividual) dos direitos fundamentais econômicos, sociais, culturais e ambientais. Revista de Direitos Fundamentais e Democracia, v. 14, n. 14, Curitiba, p. 618-688, jul. /dez. 2013.

${ }^{7}$ Conforme observado por ÁVILA e WIERZCHOWSKI, embora tradicionalmente denominadas de normas programáticas, passaram a ser consideradas normas-princípios, a fim de conferir-lhes maior normatividade. In Fair Play Judicial na efetivação dos direitos sociais: da crítica ao ativismo judicial concretista à defesa do controle material das leis orçamentárias pelo Poder Judiciário. In Revista Direitos Fundamentais \& Justiça v. 7, n. 23, abr/jun 2013, p. 192-225, p. 196.

${ }^{8}$ MENDES, Gilmar Ferreira. COELHO, Inocência Mártires. BRANCO, Paulo Gustavo Gonet. Hermenêutica constitucional e direitos fundamentais. 1. ed. 2. tir. Brasília: Brasília Jurídica, 2002, p. 40-1 (grifo original).

${ }^{9}$ RAMOS, Elival da Silva. Ativismo Judicial- Parâmetros Dogmáticos. São Paulo: Saraiva, 2010, p.191.
} vol.10, n. 01, Rio de Janeiro, 2017. pp. 519-543 
Elaborar uma síntese sobre este que é um dos temas centrais de debate nas democracias constitucionais modernas - a realização dos direitos sociais e econômicos no âmbito do Poder Judiciário - é tarefa bastante difícil. Isso porque, nesta questão, tudo é discutível e nada se presta à simplificação extrema.

Discute-se, em primeiro lugar, se os direitos sociais e econômicos podem ser considerados direitos. Argumenta-se que o direito é uma pretensão concernente apenas à liberdade de o indivíduo fazer o que bem entender da sua própria vida sem a interferência de outrem ou do próprio Estado. Nas palavras de Hart, "os direitos conferem a seus titulares o poder de controlar a conduta dos outros" ${ }^{\prime 10}$. Isso flerta com a ideia de que somente os direitos negativos, i.e., aqueles que impõem uma abstenção dos outros em face de seu titular, se enquadrariam na ideia de direito. Já os direitos sociais e econômicos (que são direitos a prestações positivas) são pretensões decorrentes da escassez de recursos que escapam do espaço de autoridade para a tomada de decisões com autonomia: "o objetivo deles é proteger as pessoas não apenas contra o que se faz a elas, mas também contra o que lhes acontece sem a intervenção de mais ninguém" ${ }^{11}$. Compreendendo pretensões relacionadas à saúde, educação, moradia e alimentação, entre outros, esses direitos se apresentam confrontados pela inerente limitação da escassez, implicando uma impossibilidade lógica de serem definidos de modo categórico e incondicional ${ }^{12}$. Onde simplesmente não há, não há direito.

Em segundo lugar, argumenta-se que o reconhecimento desses direitos cria graves interferências na própria liberdade individual, à medida que o grau de contribuição da sociedade para sua satisfação gera problemas de aplicação muito difíceis de contornar. Essa interferência que põe em risco a liberdade aparece de modo contundente nas palavras de Charles Fried: "não há dúvidas de que eu tenho o direito de fazer da minha vida qualquer outra coisa que não seja dedicá-la integralmente a alimentar aqueles cuja fome eu poderia evitar se trabalhasse dia e noite para esse fim"13.

Esses dois pontos de debate, isolados, já deixam entrever a complexidade da questão. Somam-se a isso outros dois ingredientes que levam adiante a discussão: (a) o modo de previsão dos direitos sociais e econômicos nas constituições modernas, onde aparecem, em grande parte, indefinidos e carentes de concretização, e (b) a necessidade de que a sua realização prática, em face da omissão dos poderes diretamente responsáveis, passe pela definição dos tribunais - os autênticos intérpretes dos textos constitucionais.

A partir daí diversas questões entram em pauta quanto à efetivação desses direitos pelo Poder Judiciário, suscitando dificuldades interligadas à democracia, à missão institucional do processo judicial e à separação de poderes. Essas questões estão bem articuladas no trabalho de David Beatty - A Essência do Estado de Direito

\footnotetext{
${ }^{10}$ HART, H. L. A. Are There Any Natural Rights? ApudBEATTY, David M. A Essência do Estado de Direito. Tradução de Ana Aguiar Cotrim. São Paulo: Martins Fontes, 2014, p. 220

${ }^{11}$ BEATTY, David M. A Essência do Estado de Direito. Tradução de Ana Aguiar Cotrim. São Paulo: Martins Fontes, 2014, p. 221.

${ }^{12}$ Idem, ibidem.

${ }^{13}$ FRIED, Charles. Right \& Wrong. Apud BEATTY, op. cit., p. 222.
} 
(The Ultimate Rule of Law, Oxford University Press, 2004), traduzido para o português e publicado no ano de 2014. Em apertada síntese, Beatty lembra que, quanto à democracia, deve-se atentar para o fato de que os direitos sociais e econômicos remetem "ao modo como a sociedade distribui seus recursos e manifestam seu caráter de coletividade, atitudes essas atinentes ao povo e seus representantes eleitos, não à elite profissional”"14. Quanto à missão institucional do Judiciário, o autor descreve a posição de diversos teóricos no sentido de que o processo judicial serve para definir questões sobre o certo e o errado e a devida reparação de danos causados, a partir das provas apresentadas na fase instrutória a respeito dos fatos, que culminam com a aplicação dos deveres previamente definidos nas regras jurídicas. Para esses teóricos, os direitos sociais e econômicos não se enquadrariam nas situações para as quais os procedimentos judiciais foram moldados, pois quando postos em causa, "o que se questiona é se, ao distribuir as riquezas do Estado, a ação do governo foi justa, e não se o governo causou algum dano ao fazer o que fez. ${ }^{15}$ Lançando mão das palavras de Lon Fuller, Beatty assevera:

"os direitos sociais e econômicos manifestam de maneira clássica todas as características das
pretensões policêntricas e demonstram a total falta de aptidão do Judiciário para encontrar
um meio justo de distribuir os recursos do Estado (...) O fato de haver tantas maneiras
diferentes e igualmente legítimas de organizar a assistência médica, a moradia, a educação
etc. - no que diz respeito ao tipo de serviço, para quem e por quanto tempo - significa que o
processo judicial não é adequado para resolver demandas desta espécie, e o fato de tantos
outros poderem fazer reivindicações conflitantes pelos fundos em disputa significa que
tampouco os tribunais são adequados. Há tantas causas em que os governos podem gastar
dinheiro, bem como tantos indivíduos e grupos, que qualquer decisão tomada por um
tribunal será arbitrária e incompleta. ${ }^{16}$

Essa dificuldade apontada consiste numa das maiores críticas que se opõe ao ativismo judicial na área dos direitos sociais e está intrinsecamente ligada à questão da separação de poderes. Beatty não tem dúvidas de que este é um ponto de convergência entre a direita, a esquerda e o centro: "a imposição judicial de direitos sociais e econômicos é ilegítima porque contradiz nosso compromisso com as formas democráticas de governo" em grave menosprezo do princípio separação dos poderes ${ }^{17}$. Posta deste modo a discussão, é de questionar-se: pode o Judiciário impor ao Estado um dever pretacional específico sem que esteja previamente normatizado, determinando a alocação dos recursos públicos e assumindo a gestão das finanças do Estado?

Como já referimos, normas de direitos sociais necessitam de providências situadas "fora" do âmbito constitucional, providências estas que requerem a atuação conjunta dos Poderes Legislativo e Executivo a fim definir prioridades de modo a atender às demandas da sociedade e estabelecer os programas de Governo, prevendo dotação orçamentária para tanto - são as chamadas políticas públicas. Ou seja, exigem conhecimentos

\footnotetext{
${ }^{14}$ BEATTY, op. cit., p. 225.

${ }^{15}$ Idem, ibidem, p. 225.

${ }^{16}$ Ibid., p. 226-7

${ }^{17}$ Ibid., p. 227.
} 
técnicos e políticos no estabelecimento dessas prioridades, em especial num cenário de escassez de recursos, o que foge da competência do Poder Judiciário ${ }^{18}$.

Com efeito, o caráter eminentemente prestacional faz com que o fator custo assuma especial relevância no âmbito da eficácia e efetivação dos direitos fundamentais sociais, logo, a disponibilidade da prestação imposta pela norma encontra-se na "dependência da real existência dos meios para [o destinatário da norma] cumprir com sua obrigação" ${ }^{19}$ - daí estarem sujeitas ao que se convencionou chamar de "reserva do possível", no sentido de que “[... a prestação reclamada deve corresponder ao que o indivíduo pode razoavelmente exigir da sociedade [ ... ]" ${ }^{20}$ Neste sentido, Gustavo Amaral salienta que, diante da infinidade de necessidades e da escassez dos recursos necessários para satisfazê-las, toda escolha envolvendo prestações positivas é uma "escolha trágica", a qual deve partir de critérios para decidir as prioridades e a forma de atendê-las, decisões que tendem a ser políticas. ${ }^{21}$

Andreas Krell, já de longa data, critica o argumento de que as decisões alocativas fogem da esfera de atuação dos Tribunais. No caso de prestações ineficientes, assim como de omissão total, pondera o autor que o poder público sempre poderia justificá-las com base na indisponibilidade de recursos, razão por que a prestação de serviços precários pode e deve ser compelida e corrigida pelos Tribunais, sob pena de reduzir à zero a eficácia dos direitos sociais prestacioinais ${ }^{22}$. Nesse sentido, há muitos autores sustentando que a discricionariedade estatal deve sofrer limitações em face do dever constitucionalmente imposto de garantir o acesso aos bens sociais ${ }^{23}$.

Não se pode deixar de reconhecer que a atuação estatal está pautada, expressamente, pelo Título I da Constituição Federal, relativo aos princípios fundamentais da República Federativa do Brasil, o qual define como

\footnotetext{
${ }^{18}$ AMARAL, Gustavo. Direito, escassez e escolha: em busca de critérios jurídicos para lidar com a escassez de recursos e as decisões trágicas. Rio de Janeiro: Renovar, 2001, p. 172; ABRAMOVICH, Victor. COURTIS, Christan. Direitos sociais são exigiveis. Trad. Luis Carlos Stephanov. Porto Alegre: Ed. Dom Quixote, 2011, p.159. Os autores trazem a questão dos conhecimentos técnicos e políticos como sendo um dos argumentos sustentando por aqueles que defendem a não atuação do Poder Judiciário na efetivação dos direitos sociais, posição da qual discordam.

${ }^{19}$ SARLET, Ingo Wolfgang. A eficácia dos direitos fundamentais: uma teoria geral dos direitos fundamentais na perspectiva constitucional. 11. ed. rev. atual. Porto Alegre: Livraria do Advogado: 2012, p. 286-7. Em outra passagem (p.285) o autor enfatiza que todos os direitos fundamentais implicam um custo, o que significa que a necessidade de alocação de recursos para a efetivação de direitos fundamentais não está restrita aos direitos sociais.

${ }^{20}$ SARLET, Ingo Wolfgang. A eficácia dos direitos fundamentais: uma teoria geral dos direitos fundamentais na perspectiva constitucional. 11. ed. rev. atual. Porto Alegre: Livraria do Advogado: 2012, p. 287. KRELL observa que a construção da teoria da reserva do possível tem origem na jurisprudência constitucional alemã, que entende que os direitos subjetivos à prestação estão sujeitos à disponibilidade de recursos e que por isso a decisão acerca desta disponibilidade está incluída no âmbito de discricionariedade de políticas governamentais por meio da composição do orçamento público; em sua obra o autor critica a transferência desta doutrina para o Brasil sem as devidas adaptações, em razão da precariedade das condições socioeconômicas do país (KRELL, Andreas. Direitos sociais e controle judicial n o Brasil e na Alemanha: os (des)caminhos de um direito constitucional comparado. Porto Alegre: Sérgio Antônio Fabris Editor, 2002, p.52).

${ }^{21}$ AMARAL, Gustavo. Direito, escassez e escolha: em busca de critérios jurídicos para lidar com a escassez de recursos e as decisões trágicas. Rio de Janeiro: Renovar, 2001, p. 172.

${ }^{22}$ KRELL, Andreas. Direitos sociais e controle judicial n o Brasil e na Alemanha: os (des)caminhos de um direito constitucional comparado. Porto Alegre: Sérgio Antônio Fabris Editor, 2002, p. 51-7.

${ }^{23}$ Neste sentido: ABRAMOVICH, Victor. COURTIS, Christan. Direitos sociais são exigíveis. Trad. Luis Carlos Stephanov. Porto Alegre: Ed. Dom Quixote, 2011, 168. MELLO, Cláudio Ari. Democracia Constitucional e Direitos Fundamentais. Porto Alegre: Livraria do Advogado, 2004, p. 236.
} 
seus fundamentos e objetivos, dentre outros, a dignidade da pessoa humana, a construção de uma sociedade livre, justa e solidária, impondo ao Poder Público o dever de promover a justiça social. Segundo Cláudio Ari, o argumento da injusticiabilidade dos direitos sociais está associado à teoria política liberal dos diretos fundamentais, a qual não é compatível com o sistema constitucional brasileiro ${ }^{24}$, ao que, acrescentaríamos, também não se coaduna com a orientação visível em diversos países onde o constitucionalismo democrático está consagrado.

De fato, muitos autores que se opunham frontalmente à justiciabilidade dos direitos sociais e econômicos - em particular Cass Sunstein e Dennis David - terminaram por revisar oportunamente sua orientação, por compreenderem que é possível, ao Poder Judiciário, um meio-termo entre a imposição de prestações específicas com subversão orçamentária e a negação que contribuiria para agravar a situação de miserabilidade de indivíduos. É muito interessante o exame de David Beatty ao descrever o raciocínio empregado na obra daqueles teóricos em momento anterior e posterior a um precedente do Tribunal Constitucional da África do Sul que se tornou um marco nesta questão. Trata-se do julgamento proferido no Caso Grootboom vs. República da África do SuṔs, pelo qual o tribunal "atribuiu aos governos nacional, provinciais e municipais do país a responsabilidade conjunta de criar programas que fornecessem abrigo e ajuda emergencial para Irene Grootboom e outros igualmente desabrigados em condições críticas", numa clara demonstração de que "é possível aos tribunais oferecer ajuda significativa aos membros menos privilegiados de uma sociedade sem ter de assumir uma função administrativa inadmissível" ${ }^{\text {26 }}$. Esta determinação judicial de que os poderes responsáveis executem o planejamento necessário para efetivar uma política de moradia acessível aos grupos vulneráveis muitos deles em situação desesperadora -, engendra uma combinação entre a justiciabilidade de direitos sociais, a preservação de competências constitucionais e o coeficiente democrático necessário às deliberações estatais que versam a destinação dos recursos.

Entre nós, algo semelhante foi observado em um precedente do Superior Tribunal de Justiça do ano de 2003, em que a Ministra Eliana Calmon determinou a inclusão, no orçamento municipal do exercício seguinte, de verba própria e suficiente para o atendimento de programa de serviço de orientação e tratamento de alcoólatras e toxicômanos, lançado pelo Executivo local em seu programa de governo, mas que deixara de ser implementado por falta de verbas ${ }^{27}$.

\footnotetext{
${ }^{24}$ MELLO, Cláudio Ari Pinheiro de. Os direitos fundamentais sociais e o conceito de direito subjetivo. In: Revista do Ministério Público (Rio Grande do Sul), Porto Alegre, v. 56, p. 105-138, 2005, p. 130.

${ }^{25}$ Sobre o caso Grootboom, há interessante análise, traçando diversas similitudes entre a situação da África do Sul e a do Brasil, em MAURÍCIO JR., Alceu. A revisão judicial das escolhas orçamentárias e a efetivação dos direitos fundamentais. In Revista Diálogo Jurídico Online, n. 15, jan/2007, Salvador.

${ }^{26}$ BEATTY, op. cit., p. 231.

${ }^{27}$ REsp 493.811/SP 2002/0169619-5, Rel. Min. Eliana Calmon. STJ, 2a Turma, 10/11/2003. Ementa: ADMINISTRATIVO E PROCESSO CIVIL -AÇÃO CIVIL PÚBLICA -ATO ADMINISTRATIVO DISCRICIONÁRIO: NOVA VISÃO. 1. Na vol.10, nº. 01, Rio de Janeiro, 2017.pp. 519-543 
Percebe-se, portanto, que a atuação judicial no exercício da tutela dos direitos sociais que dependem de políticas públicas para terem garantidas a sua fruição não está necessariamente ligada à prática do ativismo, o qual se manifesta na medida em que esta atuação é desprovida de limites. Isso porque, em lugar de satisfazer diretamente as pretensões individuais, a decisão referida consiste numa determinação ao Poder Público para que agisse segundo a promessa fixada no programa de governo por ele próprio elaborado.

No Poder Judiciário observam-se tendências difusas quanto à satisfação direta de pretensões positivas reconhecidas a partir de direitos sociais e econômicos previstos de modo genérico na Constituição. ${ }^{28}$ Daí a importância em identificar, nos julgados do STF - tribunal supremo do sistema judicial brasileiro, cujos precedentes deveriam servir de referência aos órgãos judiciais hierarquicamente inferiores -, qual a tendência predominante no exercício da tutela dos direitos sociais de cunho prestacional: se a do ativismo judicial, em que o Judiciário, em clara violação ao princípio da separação dos poderes e do princípio democrático, simplesmente avoca para si as competências constitucionalmente cometidas a outros poderes para satisfazer pretensões dependentes de lei para serem concretizadas, com a consequente alocação de recursos não previstos em lei orçamentária; ou se a do self-restraint, que por um lado preserva as competências constitucionais mas, por outro, aprofunda o grave quadro de omissão na satisfação dos direitos fundamentais que devem ser assegurados segundo a Constituição; ou se acena para o meio-termo visível no já referido Caso Grootboom.

Com todas as peculiaridades e dificuldades que foram brevemente analisadas, percebe-se de pronto a complexidade desta tarefa, na qual devem ser considerados pelo magistrado argumentos não só jurídicos, mas também políticos, desafiando os limites da prática de se fazer justiça no caso concreto.

\section{EFETIVAÇÃO DOS DIREITOS SOCIAIS NO STF: ALGUNS JULGADOS}

Como já referido, optou-se por dividir os acórdãos em dois grupos. Assim, examinaremos em separado os casos relativos às demandas individuais e os casos relativos às demandas coletivas, o que nos permitirá observar se existe diferença na atuação do Poder Judiciário em razão da espécie de demanda. Serão apresentados apenas os acórdãos cuja fundamentação se deu de forma mais detalhada e que sejam representativos de uma amostragem fidedigna dos parâmetros presentes nas decisões do Tribunal.

atualidade, o império da lei e o seu controle, a cargo do Judiciário, autoriza que se examinem, inclusive, as razões de conveniência e oportunidade do administrador. 2. Legitimidade do Ministério Público para exigir do Município a execução de política específica, a qual se tornou obrigatória por meio de resolução do Conselho Municipal dos Direitos da Criança e do Adolescente. 3. Tutela específica para que seja incluída verba no próximo orçamento, a fim de atender a propostas políticas certas e determinadas. 4 . Recurso especial provido. (grifamos)

${ }^{28}$ Há vários exemplos de concessão de prestações na área da saúde independentemente de previsão legislativa e orçamentária sinalados por AVILA, Ana Paula Oliveira, WIERZCHOWSKI, Mariana R. Fair Play Judicial na efetivação dos direitos sociais: da crítica ao ativismo judicial concretista à defesa do controle material das leis orçamentárias pelo Poder Judiciário. In Revista Direitos Fundamentais \& Justiça v. 7, n. 23, abr/jun 2013, p. 192-225 


\section{Tutela dos direitos sociais em demandas individuais}

Do conjunto de julgados analisados, em treze houve a tutela individual dos direitos sociais; são eles: RE 410.715 AgR; Rel. Min. Celso de Mello, julgado em 22.11.2005 (educação); STA 175 AgR, Rel. Min. Gilmar Mendes (Presidente), julgado em 17/03/2010 (saúde); AI 750.768 AgR, Relator(a): Min. Dias Toffoli, 25/10/2011 (saúde - servidor público); ARE 801.676 AgR, Min. Roberto Barroso, julgado em 19/08/2014 (saúde); RE 820.910 AgR, Min. Ricardo Lewandowski, julgado em 26/08/2014 (saúde); AI 810.864 AgR, Min. Roberto Barroso, julgado em 18/11/2014 (saúde); ARE 838.816 AgR, Min. Gilmar Mendes, julgado em 03/02/2015 (educação/acessibilidade); ARE 860.979 AgR; Rel. Min. Gilmar Mendes, julgado em 14/04/2015 (educação/acessibilidade) ARE 879.204 AgR, Min. Rosa Weber, julgado em 28/04/2015 (saúde); ARE 875.333 ED, Rel. Min. Gilmar Mendes, julgado em 28/04/2015 (educação/acessibilidade); ARE 855.762 AgR, Rel. Min. Gilmar Mendes, julgado em 19/05/2015 (moradia); RE 696.077 AgR, Rel. Min. Rosa Weber, julgado em 02/06/2015 (saúde - imposição do dever de oferecer moradia adequada para pós-operatório de transplante de medula óssea); ARE 894.085 AgR, Rel. Min. Roberto Barroso, julgado em 15/12/2015 (saúde).

No contexto da judicialização das políticas públicas, costuma-se dizer que as demandas individuais em que se postula a concessão de prestações fáticas são as que produzem efeitos mais perversos "institucionalmente falando", por desconsiderarem a necessidade de tratamento igualitário nas questões relativas à justa distribuição dos bens sociais. ${ }^{29}$ É preciso, contudo, diferenciar o contexto em que se inserem.

Nos casos em que as opções políticas já tiverem sido instituídas pelos poderes competentes na forma de políticas públicas, não se discute a legitimidade do Poder Judiciário de, em caso de omissão da Administração Pública, dar cumprimento à lei em demandas individuais..$^{30}$ Se há lei prevendo a implementação de determinado programa social, cabe ao Poder Executivo o fiel cumprimento da lei, de acordo com as dotações e limitações impostas pelas leis orçamentárias, sob pena de caracterizar omissão ilegal por parte do Executivo, ato passível de controle jurisdicional. ${ }^{31}$ Quando a ação legislativa e administrativa já tiverem sido efetivadas no sentido de determinar as prioridades a serem atendidas para cumprir com os preceitos constitucionais, densificando-as na forma de política pública, é de ser reconhecida a pretensão individual dos respectivos beneficiários voltada à fruição do direito previsto em lei ${ }^{32}$, incumbindo ao Poder Judiciário a reparação de lesão a direito (art. 50, XXXV,

\footnotetext{
${ }^{29}$ Nesse sentido RAMOS, que defende a forma coletiva de tutela dos direitos sociais (RAMOS, Elival da Silva. O direito à saúde em face da discricionariedade... op.cit.2013, p. 501.

${ }^{30}$ BARCElloS, Ana Paula. A eficácia jurídica... (op. cit.), p. 274. RAMOS, Elival da Silva. O direito à saúde em face da discricionariedade ... op.cit., p. 496, que afirma: "[o] que os magistrados podem e devem fazer é coibir o desatendimento às normas legislativas e administrativas que completam a moldura institucional do direito à saúde [...]".

${ }^{31}$ APPIO, Eduardo. Controle das políticas públicas no Brasil. Curitiba: Juruá, 2005, p 171.

${ }^{32}$ HACHEM, Daniel Wunder. A dupla titularidade (individual e transindividual) dos direitos fundamentais econômicos, sociais, culturais e ambientais. Revista de Direitos Fundamentais e Democracia, v. 14, n. 14, Curitiba, p. 618-688, jul./dez. 2013, p. 678. vol.10, no. 01, Rio de Janeiro, 2017.pp. 519-543 527
} 
$\mathrm{CF} / 88)$. Esta foi a situação que se apresentou para julgamento nos casos do RE 410.715 AgR e do ARE 855.762 $\mathrm{AgR}^{33}$, os quais adotaram respectiva fundamentação.

No julgamento do ARE 855.762 AgR, foi mantido o acordão de origem, em que ficara determinado o dever do município de incluir o autor da ação em programas habitacionais por ter tido sua residência interditada pela Defesa Civil em razão de fortes chuvas. O Min. Gilmar Mendes observou que, no caso, o provimento judicial era no sentido de apenas determinar ao Executivo o cumprimento das políticas públicas previamente instituídas, não sendo o caso de indevida ingerência nas competências dos demais poderes.

O RE 410.715 AgR, por sua vez, envolvia pedido de matrícula de criança em creche municipal, a qual tinha sido negada pela Administração Pública por falta de vaga. O município alegava a insuficiência de recursos para ampliar o atendimento de forma a abranger todas as crianças daquele município. Pelas alegações da municipalidade, percebe-se que já havia sido implementada política social voltada a dar cumprimento ao disposto no art. 208, IV, CF/88, a qual, porém, não estava sendo executada plenamente pelo Poder Executivo. Somente por meio das alegações vertidas pelo município é que foi possível concluir que a política pública educacional para atendimento de crianças em creche já havia sido instituída, pois a fundamentação do acórdão é de caráter genérico, argumentando em prol da legitimidade do Poder Judiciário para implementar políticas públicas em caso da omissão dos demais Poderes, sem delimitar que, no caso, o que se pretendia era o cumprimento de uma obrigação já vertida em lei.

Nesses casos relatados, a atuação judicial dá-se dentro dos limites que são impostos pela sua função precípua que é, em ações ordinárias, aplicar a lei ao caso concreto, não configurando indevida ingerência nas funções atribuídas aos demais poderes, uma vez que os programas de governo já estão delimitados em lei, cabendo ao Poder Executivo executá-los. ${ }^{34}$ Nessas situações não há falar em controle de uma decisão política, o que ocorre é apenas o controle de um ato administrativo, por vinculação ao princípio da legalidade..$^{35}$

No que tange ao direito à saúde, temos instalada uma ampla estrutura administrativa de saúde pública consubstanciada na Lei do SUS. Assim, vige a orientação no sentido de dar prevalência às políticas públicas já instituídas, segundo os parâmetros estabelecidos em audiência pública realizada no âmbito do STF relativa à judicialização da saúde. Tais parâmetros foram estabelecidos a fim de guiar a atuação do Poder Judiciário nesta

\footnotetext{
${ }^{33}$ RE 410.715 AgR, Rel. Min. Celso de Mello, julgado em 22.11.2005 e ARE 855.762 AgR, Rel. Min. Gilmar Mendes, julgado em $19 / 05 / 2015$

${ }^{34}$ Como observa KRELL, no âmbito da efetivação dos direitos sociais, "não se atribui ao Judiciário o poder de criar políticas públicas”, mas sim o de impor a execução daquelas já estabelecidas na constituição ou nas leis ordinárias (op. cit., p. 94).

${ }^{35}$ APPIO, Eduardo. Controle das políticas públicas no Brasil. Curitiba: Juruá, 2005, p 171-2. Nessa obra, o autor enfatiza a diferença entre a função de governo (política) e a função administrativa; esta última manifesta-se na execução das políticas traçadas pela primeira, ou seja, a função administrativa tem caráter instrumental (p. 106-7). No que tange ao controle judicial afirma: "[o] controle judicial da Administração Pública pressupõe uma distinção entre um governo ordenado para a consecução de finalidades de natureza política [...] e uma máquina administrativa estruturada a partir de uma burocracia técnica, vocacionada a concretizar os vol.10, nº. 01, Rio de Janeiro, 2017.pp.519-543 
seara, os quais têm sido aplicados em diversas demandas, tal como se deu no julgamento da STA 175 AgR. Neste caso, o relator, Min. Gilmar Mendes, observou que o direito individual à saúde prima face está condicionado ao não-comprometimento do funcionamento do SUS e que a obrigação do Estado imposta pelo art. 196 da CF restringe-se, primariamente, à elaboração de políticas públicas formuladas para garantir o direito à saúde.

A inexistência destas políticas, porém, não impede a intervenção do Poder Judiciário, a qual deve pautarse pelos parâmetros estabelecidos após a audiência pública, que, em apertada síntese, são os seguintes: (a) o medicamento deve ter registro na ANVISA; (b) deve ser dada prioridade ao tratamento existente no protocolo do SUS, mesmo que não seja o requerido, mas desde que eficaz; ainda, (c) a inexistência de tratamento no protocolo do SUS não impede sua concessão quando o mesmo tratamento está disponível na rede privada, desde que demonstrado, por meio de prova contundente (perícia), o estado de saúde do demandante e a necessidade do medicamento para sua sobrevida.

Em que pese tenha sido determinada a prevalência das escolhas já realizadas pelos poderes competentes, foi feita uma ressalva quanto à possibilidade de ser deferida prestação que não está prevista nas políticas oficiais, o que, segundo RAMOS, acaba fundamentando e até mesmo estimulando decisões judiciais ativistas na esfera do direito à saúde. De fato, aos juízes não é concedida a competência para realizar uma escolha entre as opções terapêuticas a serem custeadas pelo sistema público - opções que são estipuladas de modo a garantir o acesso igualitário aos bens sociais num contexto de limitação recursal. ${ }^{36}$ Com base nessa ressalva, o Poder Judiciário vem reconhecendo o direito à concessão de medicamento ou de tratamento médico, muitas vezes de alto custo e para tratamento de doenças raras, não previstos na política de saúde pública, tal como ocorreu nos julgamentos da STA 175 AgR, do ARE 894.085 AgR, do AI 810.864 AgR, do ARE 801.676 AgR, do RE 820.910 AgR, do RE 696.077 AgR e do ARE 879.204 AgR ${ }^{37}$

Tais decisões que, em demandas individuais, concedem prestações fáticas que não estão especificadas na Constituição, tampouco previstas em política pública, são manifestações do ativismo judicial na jurisprudência dos Tribunais, das quais decorrem efeitos perniciosos do ponto de vista constitucional. Ao impor determinado dever prestacional que não conta com previsão legal, o Poder Judiciário, em ofensa ao princípio da separação dos poderes, está avocando para si funções atribuídas aos Poderes Legislativo e Executivo, que são os poderes competentes para eleger as prioridades sociais a serem atendidas de acordo com a utilização racional dos recursos

comandos governamentais" (BUCCI, Maria Paula Dallari. Direito administrativo e politicas públicas. Apud APPIO, Eduardo. op. cit, p. 108).

${ }^{36}$ RAMOS, Elival da Silva. O direito à saúde em face da discricionariedade... (op. cit). 2013, p. 497-8.

${ }^{37}$ ARE 894.085 AgR, Rel. Min. Roberto Barroso, julgado em 15/12/2015 (neste caso a Administração Pública, recorrente, alegava que o beneficiário da prestação não era pessoa hipossuficiente, argumento que não foi apreciado por ausência de prequestionamento); AI 810.864 AgR, Min. Roberto Barroso, julgado em 18/11/2014; ARE 801.676 AgR, Min. Roberto Barroso, julgado em 19/08/2014; RE 820.910 AgR, Min. Ricardo Lewandowski, julgado em 26/08/2014; RE 696.077 AgR, Rel. Min. Rosa Weber, julgado em 02/06/2015; ARE 879.204 AgR, Min. Rosa Weber, julgado em 28/04/2015. 
públicos. Nesses casos, as escolhas já realizadas pelos poderes democraticamente eleitos acabam sendo substituídas pelas prioridades estipuladas pelo Poder Judiciário, em afronta direta ao princípio democrático e com a consequente realocação de recursos que não contam com previsão em lei orçamentária.

O STF, porém, considera legítima essa forma de atuação; por ser o guardião da Constituição, argumenta que lhe cabe a função de tutela dos direitos sociais constitucionalmente previstos sem que isso configure violação ao princípio da separação dos poderes. Essa função, segundo entendimento da Corte, embora caiba primeiramente aos poderes democraticamente eleitos, pode ser atribuída a Poder Judiciário em casos excepcionais, que são aqueles em que a omissão desarrazoada por parte dos poderes competentes leva ao comprometimento da eficácia dos direitos fundamentais de modo a afetar o núcleo essencial do direito consubstanciado no mínimo existencial. A limitação recursal é considerada como um fator secundário, que deve ceder num juízo de ponderação em face do direito à vida. A justificação da atuação judicial, portanto, é a omissão injustificável por parte dos poderes competentes que comprometa o mínimo existencial ${ }^{38}$.

Cumpre, porém, questionar-se se nesses casos está, de fato, caracterizada uma omissão ou prestação ineficiente. Isso porque a não inclusão de determinada prestação em política pública pode ser vista como um ato legítimo de escolha política, que deve se guiar por critérios de universalidade de acesso e de utilização racional dos recursos públicos disponíveis. A concessão de prestação fática que, em razão do custo, não possa ser concedida para toda a coletividade que se enquadre na mesma situação, constitui afronta ao princípio da igualdade ${ }^{39}$, pois defere tratamento privilegiado àqueles que possuem condições de acessar a Justiça ${ }^{40}$, desconsiderando o caráter universal das políticas públicas.

Ademais, a própria inclusão de determinadas prestações fáticas no conteúdo do mínimo existencial é questão controversa. O critério da universalização da prestação num contexto de escassez recursal poderia levar à exclusão do âmbito do mínimo existencial prestações de medicamentos de alto custo para tratamento de doenças

\footnotetext{
${ }^{38} \mathrm{O}$ recurso ao mínimo existencial, porém, tem sido utilizado mais como ferramenta retórica, tendo em vista que não há uma argumentação voltada à delimitação de seu conteúdo. Na doutrina, Ana Paula Barcellos propõe alguns critérios capazes de delimitar o conteúdo do mínimo existencial; são eles: análise do custo/benefício da medida (menor custo e maior número de beneficiados) e do universo de pessoas que necessitam daquela medida (prestações que constituem a necessidade da população como um todo). A partir daí, estabelece que fazem parte do mínimo existencial do direito à saúde o saneamento básico, o atendimento materno-infantil (pré-natal, parto), as ações de medicina preventiva e ações de prevenção epidemiológica (BARCELLOS, Ana Paula. A eficácia jurídica dos princípios constitucionais: o princípio da dignidade da pessoa humana. Rio de Janeiro: Renovar, 2002, p. 274 e 280-2).

${ }^{39}$ BARREIRO, Guilherme Scodeler de Souza; FURTADO, Renata Pedretti Morais. Inserindo a judicialização no ciclo... (op.cit.), p. 306-7. ÁVILA e WIERZCHOWSKI, Fair Play Judicial na efetivação dos direitos sociais... (op. cit.), pp. 207-8.

${ }^{40}$ RAMOS, Elival da Silva. O direito à saúde... (op. cit.), 2013, p. 495 e 503-4. Segundo o mesmo autor, estas demandas acabam por agravar a desigual distribuição de riquezas pelo fato de que o acesso à Justiça está condicionado a fatores econômicos (em que pese os mecanismos de assistência judiciária gratuita), o que faz com que os maiores beneficiários sejam os "extratos médio e superior da sociedade" (p. 504).
} 
raras. $^{41}$

Feitas estas considerações, reconhece-se que prepondera o caráter ativista destas decisões, pois, a despeito de serem consideradas pelo STF como uma forma legítima de efetivação dos direitos sociais, na prática, acarretam a desestruturação do planejamento administrativo. A Administração Pública, ao ter de realocar recursos para atender as determinações judiciais, acaba por comprometer o atendimento das prioridades já estipuladas de acordo com a distribuição racional dos recursos públicos. ${ }^{42}$

No amplo catálogo de direitos sociais garantidos em nossa constituição, alguns tem seu conteúdo definido de forma mais concreta, como é o caso do direito à educação. O art. 208 da Constituição Federal fixa os meios pelos quais o dever do Estado com a educação será efetivado, especificando alguns dos deveres estatais. ${ }^{43}$ Ao Estado não é conferida margem de discricionariedade para decidir se dará, ou não, cumprimento aos deveres objetivos que decorrem das normas de direito fundamental; há uma margem para deliberação democrática quanto à escolha dos meios para atingir determinada finalidade ${ }^{44}$, espaço que é restringido na hipótese em que a própria Constituição já definiu expressamente a forma de efetivar o direito, como no caso do direito à educação fundamental. Na ausência de implementação das políticas públicas voltadas ao cumprimento desses deveres, é de ser reconhecida uma típica omissão inconstitucional, passível de ser controlada judicialmente.

Foi esta a situação que se apresentou para julgamento no ARE 860.979 AgR, no ARE 875.333 ED, e no ARE 838.816 $\mathrm{AgR}^{45}$, em que estava sendo pleiteada prestação individual para tutela do direito previsto no art. 208,

\footnotetext{
${ }^{41}$ Na doutrina, Ana Paula Barcellos propõe alguns critérios capazes de delimitar o conteúdo do mínimo existencial (considerado pela autora como um conjunto de prestações básicas fundamentais para uma existência digna cuja eficácia decorre diretamente do princípio da dignidade humana). São eles: análise do custo/benefício da medida (menor custo e maior número de beneficiados) e do universo de pessoas que necessitam daquela medida (prestações que constituem a necessidade da população como um todo e que podem ser universalizadas). A partir daí, estabelece que fazem parte do mínimo existencial do direito à saúde o saneamento básico, o atendimento materno-infantil (pré-natal, parto), as ações de medicina preventiva e ações de prevenção epidemiológica (BARCELLOS, Ana Paula. A eficácia jurídica dos princípios constitucionais: o princípio da dignidade da pessoa humana. Rio de Janeiro: Renovar, 2002, p. 274 e 280-2). No âmbito das decisões judiciais, porém, o recurso ao mínimo existencial tem sido utilizado mais como ferramenta retórica, tendo em vista que não há uma argumentação voltada à delimitação de seu conteúdo.

${ }^{42}$ RAMOS, Elival da Silva. O direito à saúde... (op. cit.), p. 504. BARCELLOS, Ana Paula. A eficácia jurídica ... (op. cit.), p. 276.

${ }^{43}$ Art.208, CF/88: O dever do Estado com a educação será efetivado mediante a garantia de: I - educação básica obrigatória e gratuita dos 4 (quatro) aos 17 (dezessete) anos de idade, assegurada inclusive sua oferta gratuita para todos os que a ela não tiveram acesso na idade própria; II - progressiva universalização do ensino médio gratuito; III - atendimento educacional especializado aos portadores de deficiência, preferencialmente na rede regular de ensino; IV - educação infantil, em creche e préescola, às crianças até 5 (cinco) anos de idade; V - acesso aos níveis mais elevados do ensino, da pesquisa e da criação artística, segundo a capacidade de cada um; VI - oferta de ensino noturno regular, adequado às condições do educando; VII - atendimento ao educando, em todas as etapas da educação básica, por meio de programas suplementares de material didáticoescolar, transporte, alimentação e assistência à saúde.

${ }^{44}$ RAMOS, Elival da Silva. O direito à saúde em face da discricionariedade administrativa. In.: MARQUES NETO, Floriano de Azevedo (coord.). Direito e administração pública: estudos em homenagem a Maria Sylvia Zanella Di Pietro. São Paulo: Atlas, 2013, p. 482-510; p. 488. HACHEM, Daniel Wunder. A dupla titularidade (individual e transindividual) dos direitos fundamentais econômicos, sociais, culturais e ambientais. Revista de Direitos Fundamentais e Democracia, v. 14, n. 14, Curitiba, p. 618-688, jul./dez. 2013, p. 653.

${ }^{45}$ ARE 838.816 AgR, Min. GILMAR MENDES, julgado em 03/02/2015; ARE 860.979 AgR, Rel. Min. Gilmar Mendes, julgado em 14/04/2015; ARE 875.333 ED, Rel. Min. GILMAR MENDES, julgado em 28/04/2015.
} 
III, CF/88, que determina o dever do Estado de garantir o "atendimento educacional especializado aos portadores de deficiência, preferencialmente na rede regular de ensino". Não há dúvidas quanto à legitimidade do Poder Judiciário para reparar lesão decorrente de omissão (art. 5, XXXV, CF/88); o que pode ser questionado é a concessão individual desta prestação fática com fundamento direto nas normas constitucionais, a qual está fundada na concepção de que toda e qualquer pretensão derivada das normas de direitos sociais possuem status de direito subjetivo, em que pese a Constituição tenha atribuído o caráter de direito público subjetivo somente ao direito de acesso ao ensino público obrigatório e gratuito (conforme art. 208, I e $\$ 1^{\circ}$ ). ${ }^{46}$

Nos casos em que não houve a implementação de uma política pública que conta com previsão constitucional, a omissão seria remediada de forma efetiva pela implementação e execução da política social pelos poderes competentes de forma a atender a toda coletividade, pretensão que demandaria a tutela coletiva do direito em questão. Daniel Wunder Hachem propõe que, em razão da multiplicidade de deveres que decorrem da dimensão objetiva dos direitos fundamentais, a cada norma de direito fundamental seja atribuída simultaneamente uma titularidade individual e transindividual, a depender da espécie de pretensão material e do tipo de tutela que se busca no momento de sua reivindicação. Segundo sua proposta:

Num momento prévio, anterior à sua realização [das políticas públicas] pelo Estado, a aspiração à concretização da faceta objetiva do direito fundamental social em questão educação, saúde, moradia, assistência ou previdência social - ostentará caráter difuso. Após o cumprimento desse dever geral, quando a ação legislativa e/ou administrativa já tiver sido levada a efeito - v.g., criação de normas procedimentais e de estruturas organizativas, implementação de serviços públicos e de políticas - será possível individualizar as parcelas de prestações estatais titularizadas por cada cidadão em concreto, possibilitando então a sua fruição individual..$^{47}$

Esses parâmetros nos permitem afirmar que a concessão em caráter individual de prestação fática não prevista em lei confere a essas decisões um caráter ativista - ainda que não tenha ocorrido uma substituição das escolhas estabelecidas democraticamente por aquelas estipuladas pelo Judiciário, pois o que se tem é uma completa omissão da política pública. Esse dado leva ao efeito da violação do princípio da separação dos poderes,

\footnotetext{
${ }^{46}$ RAMOS, Elival da Silva. Ativismo judicial: parâmetros dogmáticos. São Paulo: Saraiva, 2010, p. $266-7$.

${ }^{47}$ HACHEM, Daniel Wunder. A dupla titularidade (individual e transindividual) dos direitos fundamentais econômicos, sociais, culturais e ambientais. Revista de Direitos Fundamentais e Democracia, v. 14, n. 14, Curitiba, p. 618-688, jul./dez. 2013, p. 678. O autor traz o exemplo de uma ação na qual estava sendo requerida a tutela de direito individual de pessoa portadora de deficiência usuária de cadeira de rodas, na qual o Município de Ribeirão Preto foi condenado a garantir meio de transporte adequado (por meio de vans adaptadas). A Procuradoria de Justiça, em sede de reexame necessário, postulou que fosse ampliado os efeitos da decisão do ponto de vista subjetivo, a fim de que todos os demais cidadãos que necessitassem do serviço fossem beneficiados, pedido que foi negado. Ao trazer este exemplo, o autor defende que a decisão mais adequada do ponto de vista do direito constitucional seria dar uma solução coletiva nos termos propostos pelo Ministério Público (p. 677-8). No tema do controle das políticas públicas, essa proposta evitaria a violação ao princípio da igualdade, pois o provimento jurisdicional aproveitaria a todos que se encontram na mesma situação. Embora não seja exatamente esta a proposta do autor, pensamos que o Incidente de Resolução de Demandas Repetitivas (IRDR), previsto no art. 976 do Código de Processo Civil de 2015, pode ser um valioso instrumento processual nessas questões (Art. 976. É cabível a instauração do incidente de resolução de demandas repetitivas quando houver, simultaneamente: I - efetiva repetição de processos que contenham controvérsia sobre a mesma questão unicamente de direito; II - risco de ofensa à isonomia eà segurança jurídica).
} 
do princípio democrático e do princípio da igualdade, por garantir o exercício do direito de forma desigual entre os seus titulares. ${ }^{48}$

Pelo que pudemos analisar, o STF tem assumido uma postura ativista na tutela dos direitos sociais em demandas individuais nos casos em que a prestação postulada não está concretizada em políticas públicas ${ }^{49}$, revelando a posição da Corte no sentido de ser legítima essa forma de tutela judicial, por considerar que, assim agindo, está apenas fazendo valer a Constituição. Na prática, porém, a reiteração desta forma de tutela acaba por comprometer a própria efetivação das políticas sociais, em razão do efeito perverso sobre o planejamento orçamentário decorrente da necessidade de realocação de recursos não previstos em lei orçamentária, em detrimento do princípio da igualdade, motivo pelo qual deveriam ser evitadas.

\section{Tutela dos direitos sociais em demandas coletivas}

Dos 45 (quarenta e seis) acórdãos analisados, em 32 (trinta e dois) houve a tutela coletiva dos direitos individuais, que são os seguintes: SL 47 AgR; Rel. Min. Gilmar Mendes, julgado em 17/03/2010 (saúde); ARE 639.337 AgR; Min. CELSO DE MELLO, 23/08/2011 (educação); ARE 635.679 AgR, Relator(a): Min. DIAS TOFFOLI, julgado em 06/12/2011 (educação); AI 708.667 AgR, Min. DIAS TOFFOLI, julgado em 28/02/2012 (moradia); AI 593.676 AgR, Relator(a): Min. DIAS TOFFOLI, Primeira Turma, julgado em 28/02/2012 (saneamento básico); RE 417408 AgR, Relator(a): Min. DIAS TOFFOLI, Primeira Turma, julgado em 20/03/2012 (saneamento básico); RE 634.643 AgR, Min. JOAQUIM BARBOSA, julgado em 26/06/2012 (assistência social); AI 809018 AgR, Min. DIAS TOFFOLI, julgado em 25/09/2012 (educação); RE 642.536 AgR, Min. LUIZ FUX, julgado em 05/02/2013 (saúde); AI 835.956 AgR, Min. DIAS TOFFOLI, julgado em 07/05/2013 (acesso à justiça); AI 829984 AgR, Min. DIAS TOFFOLI, julgado em 14/05/2013 (saúde); AI 810.410 AgR, Toffoli; julgado em 28/052013 (segurança); RE 628159 AgR, Min. ROSA WEBER, julgado em 25/06/2013 (segurança pública); RE 763.667 AgR; Rel. Min. Celso de Mello, julgado em 22/10/2013 (acesso à justiça); RE 440.028, Rel. Min. Marco Aurélio; julgado em 29.10.2013 (educação/acessibilidade); RE 581.352 AgR/AM; Min. CELSO DE MELLO, 29/10/2013 (saúde); RE

\footnotetext{
${ }^{48}$ RAMOS, Elival da Silva. O direito à saúde em face da discricionariedade administrativa. In.: MARQUES NETO, Floriano de Azevedo (coord.). Direito e administração pública: estudos em homenagem a Maria Sylvia Zanella Di Pietro. São Paulo: Atlas, 2013, p. 482-510; p. 503. HACHEM, Daniel Wunder. A dupla titularidade (individual e transindividual) dos direitos fundamentais econômicos, sociais, culturais e ambientais. Revista de Direitos Fundamentais e Democracia, v. 14, n. 14, Curitiba, p. 618-688, jul./dez. 2013, p. 654. ÁVILA e WIERZCHOWSKI. Fair Play Judicial na efetivação dos direitos sociais... (op. cit.), p. $197-208$.

${ }^{49}$ Nossa amostragem não contou com um número expressivo de casos de tutela individual, talvez pelo fato de termos optado por apenas incluir acórdãos e não decisões monocráticas (que são a maioria no caso da ação de Suspensão de Tutela Antecipada STA), as quais não foram incluídas em razão da quantidade com que são encontradas na jurisprudência, cuja análise seria incompatível com as limitações deste trabalho (pelos termos de pesquisa de jurisprudência aqui empregados, teríamos encontrado em torno de 1.000 decisões monocráticas acerca do tema). Contudo os fundamentos não diferem daqueles analisados, em geral presentes nessas decisões cuja quantidade indica a prevalência de uma postura ativista na tutela individual.
} 
658.171 AgR, Rel. Min. Dias Toffoli; julgado em 01/04/2014 (meio ambiente); AI 598212 ED; Min. CELSO DE MELLO; 25.03 .2014 (acesso à justiça); AI 739151 AgR, Rel. Min. Rosa Weber, julgado em 27/05/2014 (acesso à justiça); ARE 761127 AgR, Min. ROBERTO BARROSO, julgado em 24/06/2014 (educação); RE 768825 AgR, Min. RICARDO LEWANDOWSKI, julgado em 12/08/2014 (segurança pública); ARE 769.977 AgR/DF; Rel. Min. Gilmar Mendes, julgado em 28/10/2014 (educação); ARE 727.864 AgR; Rel. Min. Celso de Mello, julgado em 04/11/2014; ARE 745745 AgR, Rel. Min. CELSO DE MELLO, julgado em 02/12/2014 (saúde); RE 669635 AgR, Min. DIAS TOFFOLI, julgado em 17/03/2015 (segurança pública); RE 796.347; Rel. Min. Celso de Mello, julgado em 24.03.2015 (meio ambiente/saneamento); ARE 891418 AgR, Rel. Min. ROSA WEBER, julgado em 30/06/2015 (educação/acessibilidade); RE 592.581; Rel. Min. Ricardo Lewndowski, julgado em 13.08.2015 (saúde/integridade preso); ADPF 347 MC, Rel. Min. Marco Aurélio, julgado em 27.08.2015 (saúde/integridade preso); RE 706.085 AgR, Rel. Min. GILMAR MENDES, julgado em 27/10/2015 (saneamento básico); ARE 886710 AgR, Rel. Min. ROSA WEBER, julgado em 03/11/2015 (educação); ARE 839629 AgR; Rel. Min. DIAS TOFFOLI, julgado em 02/02/2016 (educação/acessibilidade).

Como vimos no tópico anterior, muitas das demandas individuais estão fundamentadas numa omissão ou numa atuação ineficiente da Administração Pública no âmbito da implementação das políticas públicas; argumentamos que, nesses casos, o direito deveria ser abordado na sua dimensão coletiva, sob pena de garantir a fruição do direito de forma desigual entre aqueles que se encontram na mesma situação fática, em afronta ao princípio da igualdade. Nesse aspecto, a judicialização dos direitos sociais por meio de demandas coletivas seria uma alternativa mais desejável, pois o provimento jurisdicional aproveitaria à coletividade dos beneficiários de determinada política governamental.

Isso não significa, porém, que as demandas coletivas voltadas à efetivação dos direitos sociais não levem a uma atuação judicial desprovida dos vícios ligados à prática do ativismo. Aqui, assim como no caso das demandas individuais, é preciso diferenciar o contexto em que a judicialização se insere, bem como o conteúdo do provimento jurisdicional.

Como visto anteriormente, já se admite que, diante de uma omissão ou prestação ineficiente no âmbito das políticas sociais, possa o Judiciário determinar aos demais Poderes a adequação da política pública de forma a atingir os fins sociais. Há, contudo, uma linha tênue que demarca o ativismo judicial, entre o provimento jurisdicional que, com fundamento no princípio da vedação à proteção ineficiente ${ }^{50}$, determina que os demais poderes promovam a adequação da política pública a fim garantir a eficácia das políticas sociais e a decisão judicial que, a fim de adequar determinada política social, escolhe a forma pela qual esta deve ser estruturada de modo a

\footnotetext{
${ }^{50}$ No que tange à vedação da proteção ineficiente, HACHEM observa que "[a] falta de condições adequadas ao exercício dos direitos fundamentais em sua integralidade já implica uma inconstitucionalidade” (HACHEM, Daniel Wunder. A dupla vol.10, no. 01, Rio de Janeiro, 2017.pp. 519-543 
melhor atender aos comandos constitucionais, em substituição dos poderes competentes na tomada de decisões políticas, implicando novos deveres em desconsideração às regras já estabelecidas.

O julgamento do ARE 639.337 AgR exemplifica esta última situação acima referida. Tratava-se de Ação Civil Pública em que se postulava uma alteração da política pública de acesso à creche para crianças de zero a cinco anos de idade (art. 208, IV ${ }^{51}, \mathrm{CF} / 88$ ), por meio da qual foi imposto ao Município de São Paulo o dever de realizar a matrícula em creche que fosse próxima da residência ou do local de trabalho do responsável pela criança, sob pena de multa diária por criança não atendida. A fundamentação do acórdão faz uma longa digressão teórica acerca da legitimidade do Poder Judiciário para implementar políticas públicas em caso de omissão dos demais Poderes que comprometam a dimensão do mínimo existencial, sem detalhar a situação fática apresentada nem os argumentos apresentados pela municipalidade na tentativa de reformar o acórdão de origem. $\mathrm{O}$ relator ainda invoca o argumento da proibição do retrocesso, no sentido de vedar a regressão do nível já atingido de concretização do direito, mas não esclarece se a medida postulada já havia sido implementada pela Administração Pública e posteriormente suprimida - o que legitimaria o argumento que justifica o provimento judicial.

Ao que parece, a atuação do Poder Judiciário foi no sentido de alterar o conteúdo da política pública, impondo a forma de execução proposta pelo Ministério Público e eleita pelo Poder Judiciário, em detrimento do princípio da separação dos poderes e do princípio democrático. Ainda que se argumente que a matrícula de criança em creche de difícil acesso torna a política pública inócua, não se pode negar que a adequação promovida pelo Poder Judiciário interferiu diretamente na política pública, alterando as escolhas realizadas pelos poderes competentes. $^{52}$

A situação apresenta-se de forma distinta quando o provimento jurisdicional, diante de uma atuação ineficiente, impõe determinado dever à Administração Pública a fim de garantir a eficácia das políticas sociais já instituídas. ${ }^{53}$

Nos julgados envolvendo o direito à saúde na sua dimensão coletiva, a decisão judicial foi nesse sentido (com exceção do ARE 745.745, em que se estava diante de omissão total da Administração Pública, o qual será analisado posteriormente). No julgamento da SL $47 \mathrm{AgR},{ }^{54}$ o relator, Min. Gilmar Mendes, ao manter a decisão liminar que determinou que o município adotasse as medidas necessárias à melhoria das condições de hospital

titularidade (individual e transindividual) dos direitos fundamentais econômicos, sociais, culturais e ambientais. In.: Revista de Direitos Fundamentais e Democracia, v. 14, n. 14, Curitiba, p. 618-688, jul./dez. 2013, p. 655).

${ }^{51} \mathrm{CF} / 88$, Art. 208. O dever do Estado com a educação será efetivado mediante a garantia de: IV - educação infantil, em creche e pré-escola, às crianças até 5 (cinco) anos de idade.

52 Essa prática de ativismo poderia ter sido evitada caso fosse determinado ao município a reformulação da política de acesso à creche, sem imposição de uma forma determinada de execução.

${ }^{53}$ A maioria dos acórdãos referentes a demandas coletivas tratava de uma prestação ineficiente. Os casos envolviam políticas de saneamento básico, meio ambiente, assistência social, moradia (caso de construções em área de risco), meio ambiente, segurança pública, além de política pública de saúde e de educação.

${ }^{54}$ SL 47 AgR; Rel. Min. Gilmar Mendes, julgado em 17/03/2010. 
público (havia sido constatado falta de médicos de plantão, falta de materiais e de equipamentos, insuficiência de leitos, dentre outras questões), argumentou que o Poder Judiciário não estava criando política pública, mas apenas determinando o cumprimento de política já existente no âmbito do SUS. Nos demais julgados envolvendo o direito à saúde, embora não houvesse referência ao fato de que o Judiciário estava apenas determinando o cumprimento da política do SUS, a situação era semelhante, tendo sido determinadas, em caráter geral, melhorias na rede pública (RE 642.536 AgR, AI 829984 AgR; RE 581.352 AgR) ${ }^{55}$ ou a modificação da política pública de forma a adequá-la à lei (ARE 727.864 AgR $)^{56}$.

Alguns acórdãos envolvendo o direito à educação na sua dimensão coletiva igualmente envolviam um contexto de prestação ineficiente por parte da Administração Pública. Em grande parte deles foi imposto o dever de proceder à melhora no sistema de educação pública, em geral determinando a reforma de escolas públicas em situação precária (AI 809.018 AgR, ARE 761.127 AgR; ARE 769.977 AgR; ARE 886710 AgR) 57, ou ainda a construção de novas salas de aula a fim de ampliar o número de vagas (ARE 635.679 AgR) ${ }^{58}$.

Nestes acórdãos, a justificativa para o provimento judicial foi no sentido de que o Poder Judiciário tem legitimidade para intervir em políticas públicas a fim de efetivar direitos fundamentais, aduzindo o argumento que tem se tornado a tese predominante na jurisprudência do STF - de que "[o] Poder Judiciário, em situações excepcionais, pode determinar que a Administração Pública adote medidas assecuratórias de direitos constitucionalmente reconhecidos como essenciais, sem que isso configure violação do princípio da separação de poderes". Diante destes casos é possível questionar se se trata de imposição de deveres específicos que dependeriam de lei para serem concretizados (em afronta ao princípio democrático e da separação dos poderes) ou de deveres que decorrem das próprias determinações constitucionais. É grande a dificuldade de determinar a adequação destas decisões: se, de um lado interferem diretamente no planejamento administrativo, de outro impõem obrigações indispensáveis para implementar as finalidades traçadas nas normas constitucionais.

\footnotetext{
${ }^{55}$ RE 642.536 AgR, Min. LUIZ FUX, julgado em 05/02/2013; AI 829984 AgR, Min. DIAS TOFFOLI, julgado em 14/05/2013; RE 581.352 AgR/AM; Min. CELSO DE MELLO, 29/10/2013.

${ }^{56}$ ARE 727.864 AgR; Rel. Min. Celso de Mello, julgado em 04/11/2014. Caso de custeio de internação em hospital privado quando, em atendimento de emergência pela SAMU, não houvesse leitos em hospitais públicos. A fundamentação do acórdão, mais uma vez, faz pouca referência ao caso concreto, tampouco informa que já havia normativa governamental disciplinando o custeio de internação em hospitais privados, informação que obtivemos somente por meio da consulta ao acórdão de origem, cuja numeração constava na decisão monocrática - localizada na página do "acompanhamento processual". Ao ter acesso ao acordão de origem, observamos que a controvérsia se deu em torno da competência para determinar a internação em hospital privado, se pelo diretor da central de leitos, tal como era executado pelo município, ou se pelo medico da SAMU, tal como estava estipulado em Portaria do Ministério da Saúde.

${ }^{57}$ AI 809018 AgR, Min. DIAS TOFFOLI, Primeira Turma, julgado em 25/09/2012. Neste caso o TJ local havia adotado uma postura de autocontenção, pois considerou que tal decisão está sujeita ao juízo de conveniência e oportunidade por parte da Administração Púbica, acórdão que foi reformado pelo STF. ARE 761127 AgR, Min. ROBERTO BARROSO, Primeira Turma, julgado em 24/06/2014; ARE 769.977 AgR; Min. Gilmar Mendes; 28/10/2014, ARE 886710 AgR, Min. ROSA WEBER, Primeira Turma, julgado em 03/11/2015

${ }^{58}$ ARE 635679 AgR, Relator(a): Min. DIAS TOFFOLI, Primeira Turma, julgado em 06/12/2011.
} 
Vejamos por exemplo o acórdão RE 440.028,59 que envolvia o dever de promover a acessibilidade a prédios públicos, no caso, uma escola pública. O relator, Min. Marco Aurélio, argumentou que, embora caiba à Administração Pública a escolha dos meios dentre as opções políticas disponíveis para concretização das normas constitucionais, o Judiciário está legitimado a intervir quando, por força da própria Constituição ou de dispositivos legais, as opções de escolha da Poder Público ficam restringidas. Neste particular, o relator fez alusão à incorporação da Convenção Internacional sobre os Direitos das Pessoas com Deficiência por meio da sistemática do art. $5^{\circ}, \$ 3^{\circ}$, bem como à Lei no $7.853 / 1989$, que dispõe sobre o direito das pessoas com deficiência, tratando, dentre outras questões, da acessibilidade na educação e nas edificações. ${ }^{60}$ Chamamos a atenção de que o provimento judicial deu-se no sentido de determinar o cumprimento de uma obrigação que, embora inespecífica, era "altamente previsível" em razão das disposições constitucionais e legais vigentes, o que justificaria sua legitimidade. ${ }^{61}$

Em apenas seis dos casos de demandas coletivas estava-se diante de uma omissão total dos poderes competentes quanto à implementação de políticas públicas para tutela de direitos fundamentais garantidos constitucionalmente. Quanto ao direito à educação, o ARE 839.629 AgR determinou que o município cumprisse com o dever de fornecer monitor para atendimento de crianças portadoras de deficiência, imposto pelo que consta no art. 208, III, CF/88. Outros envolviam a omissão quanto à efetivação do direito ao acesso à justiça, nos quais foi imposto o cumprimento do dever de implementação da Defensoria Pública nos Estados em que inexistia (RE 763.667 AgR; AI 598.212 ED; AI 739.151 AgR). Em relação ao direito à saúde, no ARE 745.745 AgR, o STF determinou a implementação de rede de assistência à criança e ao adolescente com deficiência e portadoras de doenças mentais.

Assim agindo o Judiciário não invade a competência administrativa de regulamentar a política pública, pois, num contexto de omissão, apenas determina formulação e implementação pelos entes para tanto competentes $^{62}$ - além do fato de preservar o caráter universal da política pública no tange à sua implementação. Não se ignora, porém, que a determinação dessas obrigações muitas vezes em caráter liminar sob pena de multa, acaba por afetar a gestão administrativa e orçamentária, pois requerem uma série de providências de ordem financeira e organizacional, com a consequente alocação de recursos que não estavam previstos em lei

\footnotetext{
${ }^{59}$ RE 440.028, Rel. Min. Marco Aurélio; julgado em 29.10.2013. O julgamento do ARE 891.418 AgR, Rel. Min. Rosa Weber, julgado em 20.06.2015 foi no mesmo sentido.

${ }^{60} \mathrm{O}$ Tribunal de origem havia exercido a autocontenção, por considerar que estava na esfera de discricionariedade administrativa decidir a respeito da conveniência de reforma na escola.

${ }^{61} \mathrm{O}$ Min. Marco Aurélio, ainda, pontuou os requisitos que legitimam a interferência do Poder Judiciário nas políticas públicas, os quais correspondem à tese prevalente no STF, que são: natureza constitucional da política pública; correlação entre esta e os direitos fundamentais; comprovada omissão ou prestação ineficiente injustificáveis.

${ }^{62}$ Nesse sentido o posicionamento de ÁVILA, Humberto. Ativismo Judicial e Direito Tributário. In. Grandes questões atuais do Direito Tributário, 15.vol., Valdir de Oliveira Rocha (Coord.). São Paulo: Dialética,2011, pp. 150-159; p. 152. 
orçamentária, podendo levar ao comprometimento das demais prioridades estipuladas. ${ }^{63}$

O impacto orçamentário dessas decisões (e essa observação abrange igualmente as demandas individuais) faz transparecer a contradição existente na relação entre Poder Judiciário e orçamento público, pois, de um lado, o Judiciário se abstém de exercer o controle prévio e direto sobre o conteúdo das leis orçamentárias, mas, de outro, subverte as alocações estabelecidas pelos poderes responsáveis num momento posterior. Em razão do caráter essencial do orçamento público para a plena efetivação dos direitos sociais, ao Judiciário caberia realizar um controle prévio quando as leis orçamentárias não atenderem aos fins constitucionais. ${ }^{64}$

No que tange ao controle das políticas públicas, o efeito perverso no planejamento administrativo e orçamentário poderia ter sido evitado se as decisões concedessem à Administração Pública prazo para realização do planejamento administrativo e orçamentário, tal como determinado no Resp no 493.811, de relatoria da Min. Eliana Calmon, ao qual nos referimos no item 2 supra. Essa tendência mais cooperativa na relação entre o Poder Judiciário e Executivo vem sendo introduzida na jurisprudência do STF, conforme pudemos observar em alguns dos acórdãos selecionados.

No RE 592.5881 estava sendo discutida a possibilidade de o Poder Judiciário determinar a reforma de estabelecimento prisional em condições precárias. Neste caso, os ministros salientaram que o Poder Judiciário estava apenas fazendo cumprir aquilo que já fora estipulado pela Administração Pública, pois a política pública já havia sido formulada com previsão para realização das obras, a qual não tinha sido executada por omissão administrativa. ${ }^{65}$ Ou seja, estava-se diante do descumprimento daquilo que já havia tomado forma na lei. Não vislumbramos qualquer espécie de ativismo judicial no provimento judicial que simplesmente determina que se cumpra a lei.

Em seu voto, o Min. Roberto Barroso fez importantes considerações acerca dos limites da atuação judicial nos casos de controle das políticas públicas. O Ministro observou que a melhor maneira de o Judiciário intervir em situações dessa espécie, de um modo geral, é impondo ao Executivo a realização de um diagnóstico da situação e a elaboração de um plano de ação a fim de sanar a omissão, com o devido monitoramento pelo Pode Judiciário, e não determinando de forma impositiva aquilo que deve ser feito. Esta, segundo o Min. Roberto Barroso, seria a forma mais adequada de convivência entre os poderes, por ser aquela que promove um diálogo

\footnotetext{
${ }^{63}$ A titulo de reflexão, podemos questionar se esse não seria um tipo de ativismo que devêssemos tolerar diante da omissão persistente dos poderes competentes de fazer cumprir as normas constitucionais garantidoras de direitos fundamentais.

${ }^{64}$ KRELL, Andreas. Direitos sociais e controle judicial n o Brasil e na Alemanha: os (des) caminhos de um direito constitucional comparado. Porto Alegre: Sérgio Antônio Fabris Editor, 2002, p. 99. Sobre a possibilidade de controle material de constitucionalidade das leis orçamentárias cf. AVILA, Ana Paula Oliveira, WIERZCHOWSKI, Mariana R. Fair Play Judicial na efetivação dos direitos sociais: da crítica ao ativismo judicial concretista à defesa do controle material das leis orçamentárias pelo Poder Judiciário. In Revista Direitos Fundamentais \& Justiça v. 7, n. 23, abr/jun 2013, p. 192-225.

${ }^{65}$ O Min. Gilmar Mendes ressaltou: "O Judiciário na o esta】 assumindo as tarefas ti冈picas do Poder Executivo, da Administraçã o

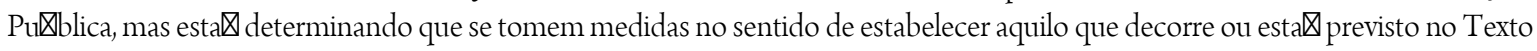
Constitucional - [...] -, mas que foi amplamente densificado na legislaça ${ }^{\circ}$ o infraconstitucional”.
} 
institucional. Ressaltou, porém, que o caso concreto merecia uma exceção, isso porque a política pública já estava formulada, havendo, portanto, previsão para realização das obras, que ainda não haviam sido executadas; logo, não se estava diante de uma intervenção para elaborar a política pública, mas sim de executar o que já estava determinado. Neste sentido mostra-se plenamente legítimo o provimento jurisdicional.

O posicionamento do Min. Roberto Barroso em relação ao diálogo institucional expressa aquela tendência que mencionamos na primeira parte deste estudo e indica uma postura mais compromissada quanto aos limites do Poder Judiciário no controle das políticas públicas de cunho prestacional. A ideia geral da cooperação institucional, embora tenha o caráter de obter dicta, pode se tornar uma tendência na Corte na medida em que passe a influenciar julgamentos futuros.

O tema voltou à pauta do STF na ADPF 347 MC, também envolvendo a intervenção do Poder Judiciário na política carcerária. O pedido, invocando a "teoria do estado de coisas inconstitucional", era justamente no sentido de que o Judiciário adotasse uma postura dialógica voltada à coordenação e monitoramento da ação dos demais Poderes a fim de promover o efetivo cumprimento dos comandos constitucionais. Embora o relator, Min. Marco Aurélio, tenha acatado a possibilidade de o Poder Judiciário cooperar no planejamento das políticas públicas por meio do diálogo institucional, o dispositivo do julgamento da medida cautelar apenas determina o cumprimento daquilo que já está estabelecido no Código Penal (no que tange às hipóteses de prisão preventiva) e na LC no 79/1994 (no tocante ao cumprimento do repasse de recursos ao FUNPEN, os quais haviam sofrido contingenciamento). Somente com o julgamento definitivo da ADPF é que poderemos confirmar se essa tendência de uma postura menos impositiva e mais dialógica do Poder Judiciário vai se firmar na jurisprudência da Corte.

Em suma, pelo que se pôde observar nos acórdãos recém analisados, diante de demandas coletivas voltadas à tutela de direito social de cunho prestacional o Judiciário incide em menor escala na prática do ativismo judicial, pois tem preservado o caráter universal das políticas públicas ao impor, em geral, um dever prestacional já previsto, explícita ou implicitamente, pelas normas constitucionais. Isto indica a preferência deste meio para a tutela dos direitos sociais nos casos de falhas ou omissão total na implementação das políticas públicas.

\section{CONCLUSÕES}

A partir da análise dos casos julgados, pudemos observar que o Poder Judiciário tem considerado legítima a sua atuação no controle das políticas públicas de cunho prestacional, defendendo a possibilidade de implementar políticas públicas quando diante de omissões injustificáveis dos demais Poderes que comprometem a eficácia dos direitos fundamentais. O Judiciário, assim agindo, estaria apenas tutelando os direitos fundamentais, sem incorrer, portanto, na violação do princípio da separação dos poderes. 
Observamos, porém, que o Poder Judiciário, na tarefa de tutela dos direitos sociais prestacionais, tem incorrido na prático do ativismo, cuja manifestação depende do contexto que se apresenta para julgamento e do provimento jurisdicional.

Foram três as situações identificadas nos julgados: (1) a política pública já existe, e o Judiciário, ao deferir determinada prestação, está apenas a determinar seu cumprimento; (2) a politica pública já foi implementada, está sendo executada e o Judiciário concede prestação que não foi previamente incluída pelo Poder Público; (3) inexistência da política pública de cunho social e o Judiciário determina que seja implementada.

Na situação número 1, o que se verifica é a determinação do cumprimento daquilo já previsto lei. É a função jurisdicional stricto sensu, típica, sem que se verifique qualquer exacerbação no exercício das competências constitucionalmente cometidas ao Judiciário. No caso de provimento judicial no sentido de fazer cumprir os deveres prestacionais já concretizados em políticas públicas, portanto, não se vislumbra qualquer forma de ativismo, seja em demandas coletivas, seja em demandas individuais, pois nestes casos já houve prévia intermediação dos poderes competentes para formular as políticas públicas.

É na situação 2, isto é, no caso em que o Judiciário determina os meios para execução das políticas públicas, impondo deveres que não foram concretizados pelos poderes competentes, que o ativismo se manifesta de forma mais acentuada, tanto em demandas coletivas quanto em individuais. A violação ao princípio democrático por sobreposição da decisão judicial às normas instituídas pelos demais poderes deslegitima essa forma de atuação judicial, além do fato de que, numa demanda individual, tem-se rompida a justa distribuição dos bens sociais que deve guiar a formulação de políticas públicas. Tais decisões judiciais alocativas de recursos não contemplados pelas políticas públicas violam o princípio da separação dos poderes e o princípio democrático, por desprezarem a necessária atuação do legislador e da Administração Pública na elaboração das políticas públicas garantidoras dos direitos sociais, densificando os deveres estatais próprios ao atendimento das prioridades selecionadas - atribuições que a Constituição confere aos Poderes eleitos. ${ }^{66}$

Por fim, tem-se a situação 3, em que a atuação judicial dá-se no sentido de apenas fazer cumprir os comandos constitucionais que garantem a tutela de direitos sociais, num contexto de inexistência de política pública ou de prestação ineficiente. Havendo o deferimento de uma prestação fática individual nesses casos, entendemos que está caracterizada uma forma de ativismo, ainda que moderada, por sobreposição da função judicial à legislativa e desvirtuamento do caráter igualitário de distribuição de recursos, embora não se negue que o Poder Judiciário, ao sanar a omissão, está tutelando direito fundamental, por reparação da lesão decorrente da omissão.

\footnotetext{
${ }^{66}$ ÁVILA, Ana Paula Oliveira, WIERZCHOWSKI, Mariana R. Fair Play Judicial na efetivação dos direitos sociais: da crítica ao ativismo judicial concretista à defesa do controle material das leis orçamentárias pelo Poder Judiciário. In Revista Direitos Fundamentais \& Justiça v. 7, n. 23, abr/jun 2013, p. 192-225, p. 203.
} 
Situação diversa ocorre quando, por meio de demanda coletiva, geralmente por ação civil púbica, o Poder Judiciário determina que os poderes competentes tomem providências no sentido de formular e implementar a política pública para atender prioridade já fixada na Constituição Federal. Nesse caso, as competências legislativas e administrativas restam preservadas, havendo apenas uma determinação para que executem suas funções e cumpram seus deveres; tampouco há violação ao princípio de justiça distributiva que guia a formulação de políticas públicas, pelo caráter geral com que será implementada. A prática de impor liminarmente a execução de políticas públicas mereceria ser revista por desrespeitar as regras atinentes à dotação orçamentária para concretização de políticas públicas.

Assim, a fim de evitar um grande impacto em termos de planejamento econômico, consideramos que o mais adequado seria a adoção de uma postura dialógica na missão jurisdicional de tutela dos direitos fundamentais prestacionais. Essa forma de atuação coloca o Poder Judiciário numa posição de cooperador com os demais Poderes na consecução dos fins sociais do Estado, possibilitando, conforme já foi referido, a tutela dos direitos fundamentais sociais, o respeito à independência dos Poderes, e a preservação do caráter democrático das decisões alocativas de recurso.

Essa espécie de terceira via de atuação judicial na judicialização das políticas públicas, com o Judiciário colocando-se como um articulador entre os demais poderes, potencializa as capacidades institucionais, fazendo com que a função desempenhada por um poder complemente a de outro de forma a melhor garantir a efetividade dos direitos fundamentais sociais, além de incrementar o coeficiente democrático por ampliação dos atores envolvidos.

Enquanto essa tendência não se consolida, o que se observou é que o STF adota uma postura ativista no controle das políticas públicas, manifestada com maior intensidade nas demandas individuais para tutela de direitos sociais. Nas demandas coletivas, que consubstanciam a maioria dos casos analisados, a tendência é pela adoção de uma postura não ativista, sinalizando uma preferência por esta forma de tutela em deferência à futura (e breve) instituição da política governamental pelos órgãos legitimamente responsáveis.

\section{BRAZILIAN SUPREME COURT ON SOCIAL RIGHTS ENFORCEMENT: JUDICIAL ACTIVISM OR SELF RESTRAINT?}

\section{Abstract}

This paper presents different scenarios of judicial intervention by the Brazilian Supreme Court on public policies, specially regarding to social and economic rights. The research has examined 45 decisions involving social rights, which were divided into two categories, distinguishing individual and collective claims. In each sampling, by pointing out the Court's arguments on that matter, we tried to identify the existence, if any, of a predominant 
doctrine in the Court's jurisprudence, such as the judicial activism or the self-restraint doctrine, or even a possible new trend on the so called "institutional dialogue theory".

Keywords: Brazilian Supreme Court; Social Rights; Judicial Activism; Judicial Self-Restraint; Public Policies.

\section{BIBLIOGRAFIA}

ABRAMOVICH, Victor; COURTIS, Christan. Direitos sociais são exigiveis. Trad. Luis Carlos Stephanov. Porto Alegre: Ed. Dom Quixote, 2011.

AMARAL, Gustavo. Direito, escassez e escolha: em busca de critérios jurídicos para lidar com a escassez de recursos e as decisões trágicas. Rio de Janeiro: Renovar, 2001.

APPIO, Eduardo. Controle Judicial das Políticas Públicas no Brasil. Curitiba: Juruá, 2005

AVILA, Ana Paula Oliveira, WIERZCHOWSKI, Mariana R. Fair Play Judicial na efetivação dos direitos sociais: da crítica ao ativismo judicial concretista à defesa do controle material das leis orçamentárias pelo Poder Judiciário. In Revista Direitos Fundamentais \& Justiça v. 7, n. 23, abr/jun 2013, p. 192-225.

ÁVILA, Humberto. Ativismo Judicial e Direito Tributário. In. Grandes questões atuais do Direito Tributário, 15.vol., Valdir de Oliveira Rocha (Coord.). São Paulo: Dialética, pp. 150-159, 2011.

BARCELLOS, Ana Paula de. A eficácia jurídica dos princípios constitucionais: o princípio da dignidade da pessoa humana. Rio de Janeiro: Renovar, 2002.

BARREIRO, Guilherme Scodeler de Souza; FURTADO, Renata Pedretti Morais. Inserindo a judicialização no ciclo das políticas públicas. In.: Revista de Administração Pública, v. 49, n.2, mar./abr., 2015, pp. 293-314.

BEATTY, David M. A Essência do Estado de Direito. Tradução de Ana Aguiar Cotrim. São Paulo: Martins Fontes, 2014.

HACHEM, Daniel Wunder. A dupla titularidade (individual e transindividual) dos direitos fundamentais econômicos, sociais, culturais e ambientais. Revista de Direitos Fundamentais e Democracia, v. 14, n. 14, Curitiba, p. 618-688, jul./dez. 2013.

KRELL, Andreas. Direitos sociais e controle judicial n o Brasil e na Alemanha: os (des) caminhos de um direito constitucional comparado. Porto Alegre: Sérgio Antônio Fabris Editor, 2002.

LEAL, Mônia Clarissa Henning; ALVES, Felipe Dalenogare. Judicialização e ativismo judicial: o Supremo Tribunal Federal entre a interpretação e a intervenção na esfera de atuação dos demais poderes. Rio de Janeiro: Lumem Juris, 2015.

MELLO, Cláudio Ari Pinheiro de. Os direitos fundamentais sociais e o conceito de direito subjetivo. In: Revista do Ministério Público (Rio Grande do Sul), Porto Alegre, v. 56, p. 105-138, 2005.

Democracia Constitucional e Direitos Fundamentais. Porto Alegre: Livraria do Advogado, 2004. 
MENDES, Gilmar Ferreira. COELHO, Inocência Mártires. BRANCO, Paulo Gustavo Gonet. Hermenêutica constitucional e direitos fundamentais. 1. ed. 2. tir. Brasília: Brasília Jurídica, 2002

RAMOS, Elival da Silva. O direito à saúde em face da discricionariedade administrativa. In.: MARQUES NETO, Floriano de Azevedo (coord.). Direito e administração pública: estudos em homenagem a Maria Sylvia Zanella Di Pietro. São Paulo: Atlas, 2013, p. 482-510.

Ativismo Judicial - Parâmetros Dogmáticos. São Paulo: Saraiva, 2010.

SARLET, Ingo Wolfgang. A eficácia dos direitos fundamentais: uma teoria geral dos direitos fundamentais na perspectiva constitucional. 11. ed. rev. atual. Porto Alegre: Livraria do Advogado: 2012.

Trabalho enviado em 17 de maio de 2016.

Aceito em 24 de julho de 2016. 